\title{
Lewis Harcourt's Journal of the 1914 War Crisis
}

\section{Edited and Introduced by John W. Young, University of Nottingham}

Lewis Harcourt (1863-1922), known as 'Loulou', was the son of the prominent Liberal politician, William Harcourt. The bond between them was particularly strong, possibly because Loulou's mother died immediately after his birth, and after school at Eton he became secretary to his father, who held the positions of Home Secretary, Chancellor of the Exchequer and, in 1896-98, Leader of the Opposition. Although frequently involved intrigue, notably when Sir William tried to succeed Gladstone as premier in 1894, Loulou did not enter Parliament until 1904. Cooler-tempered, subtler and less domineering than his father, if also less driven and passionate, he spent most of his career in government, becoming First Commissioner of Works in 1905, promoted to the Cabinet in 1907 and, the following year, taking up the more significant post of Colonial Secretary, which he held until $1915 .{ }^{1}$ Despite his privileged background - one of his great-grandfathers was an Archbishop of York, another the First Earl of Clarendon, a Cabinet minister under George III - he followed his father in aligning with radical causes like the introduction of death duties, scepticism about Imperial expansion, support for Irish Home Rule and opposition to the Boer War. But his was a traditional form of radicalism that made him sceptical about women's suffrage and Lloyd George's 'People's Budget' of 1909. Having criticised increased naval spending and, when these were disclosed in 1911, military talks with France, it was predictable that he would oppose involvement in European

\footnotetext{
${ }^{1}$ For biographies see: Patrick Jackson, 'Lewis Harcourt', Journal of Liberal History, No. 40 (Autumn, 2003), 14-17; Patrick Jackson, 'Harcourt, Lewis Vernon', Dictionary of National Biography (Oxford University Press, 2004) at http://www.oxforddnb.com/index/33/101033692/Lewis-Harcourt (accessed 31 January 2017).
} 
war in Summer 1914 but, as will become evident below, like most initial sceptics in the Cabinet, he was eventually won over.

Harcourt kept a journal for many years and parts have already been published. ${ }^{2}$ Originals of all entries below are at the Bodleian Library, Oxford in file Ms. Eng. c. 8269 of the 'Further Papers of Lewis Harcourt', which came to light in 2008, and most are available online as photographic copies of the handwritten originals $^{3}$, with shorter selections also appearing in a collection of primary sources, edited by Mike Webb, on Britain and the First World War. ${ }^{4}$ Harcourt generally wrote his original rough notes of Cabinet meetings on copies of Foreign Office telegrams, which were routinely circulated to ministers. Most of these notes were rewritten more neatly by him, apparently soon afterwards, to form a political journal, with stylistic changes to make them more easily understandable and the addition of some extra details, including events that occurred outside the Cabinet. ${ }^{5}$ His decision to take down such a record did not go unnoticed and he recorded that, during a meeting on 22 July 1914, Winston Churchill, the First Lord of the Admiralty, 'remonstrated with me for taking notes of Cabinet proceedings, so I desisted... ${ }^{6}$ But, within a few days he was back to his old habit. Historians can be grateful that he did so because no official records were taken of Cabinet meetings before 1916, apart from short reports by the Prime Minister, or his deputy, to the King. There are some diary entries, letters and memoranda left by those involved, but the only source with comparative detail to

\footnotetext{
${ }^{2}$ Patrick Jackson, (ed.), Loulou: selected extracts from the journals of Lewis Harcourt, 1880-95 (Madison, NJ: Fairleigh Dickinson University Press, 2006).

${ }^{3}$ Bodleian Library, 'War or Peace? Ten Days in the Summer of 1914, Parts 1 and 2', Monthly Archives: July 2014 and August 2014, online at https://ww1centenary.bodleian.ox.ac.uk/2014/07/ and https://ww1centenary.bodleian.ox.ac.uk/2014/07/ (accessed 31 July 2017)

${ }^{4}$ Mike Webb, From Downing Street to the Trenches: first-hand accounts from the Great War, 1914-16 (Oxford: Bodleian Library, 2014).

${ }^{5}$ The telegrams on which the original notes were written are now in file Ms. Eng. c. 8284 at the Bodleian Library.

${ }^{6}$ Bodleian Library, Oxford, Ms.Eng.c.8269, Political Journal, 22 July 1914.
} 
Harcourt's is the diary kept by the education minister, Jack Pease, which has already been published. ${ }^{7}$ One benefit of having both diaries is that they together provide a full, if personal impression of all the Cabinet meetings during the crisis. While Harcourt missed the Cabinet of 24 July, when the international crisis was first mentioned (though Ireland took up most time), Pease was present; and Pease missed the session of 1 August, which Harcourt attended.

Below is typed out the whole neat version of the journal from 26 July, when Harcourt first mentions the international crisis, until 4 August, when Britain declared war on Germany. It follows the handwritten version closely, including Harcourt's punctuation, underlinings, abbreviations (with less obvious ones being spelt out via squared brackets) and tendency to write points up in short, often one-sentence entries, rather than in paragraph form. It respects his deletions (which are few), but includes his insertions above the text (which were evidently done as part of a single writing process, rather than added later). Most of the lines that he inserted between points have, however, been omitted, while the few squared brackets [ ] he used have been altered to round brackets ( ), in order to avoid confusion with explanatory points inserted by the editor. Also included are a few notes exchanged between Harcourt and his colleagues during meetings. He evidently lacked time to write out a neat journal entry for 1 August, so for that date two rough sets of notes are reproduced, of the sort he also wrote on the back of Foreign Office telegrams. There are also three notes of separate meetings he attended on 4 August, the day Britain went to war.

\footnotetext{
${ }^{7}$ Keith Wilson (ed.), 'The Cabinet Diary of J.A. Pease, 24 July-5 August 1914', Proceedings of the Leeds Philosophical and Literary Society, Vol. XIX, No. 3 (1983), 3-13.
} 
I am grateful to the Bodleian Library for their kind permission to publish these edited excerpts from the diary.

\section{July, Political Journal}

'Nuneham ${ }^{8}$ 26.7.14 (Sunday)

A Cabinet was called for 3.15 on Friday last, after I had started for here by motor \& I cd. not get back in time.

\section{The Buckingham Pal. Conference ${ }^{9}$ had just then broken down}

I motored over this morning to see Asquith ${ }^{10}$ at Sutton Courtenay ${ }^{11}$ to know what had happened. He s[ai]d. the Cab. had decided to go on with the $2^{\text {nd }} \mathrm{R}$ [eading]. of the Amending Bill ${ }^{12}$ on Tuesday and we are to announce that we shall omit from it the time limit. Redmond ${ }^{13}$ and Co. very much disturbed and may abstain from the $2^{\text {nd }} \mathrm{R}$. division: if they do so (supported by the Lab. Party) \& the Opposition vote against, we shall be beaten ${ }^{14}$ - but I don't think it will come to this.

\footnotetext{
${ }^{8}$ Nuneham House, Nuneham Courtenay, Oxfordshire, owned by the Harcourt family since the 1750s.

${ }^{9}$ The Buckingham Palace conference, 21-24 July, hosted by King George V, sought to resolve political differences that threatened to plunge Ireland into civil war following the passage of the Government of Ireland Act. The conference brought together Liberal ministers with leaders of both the Irish Nationalists (who favoured the creation of a devolved, 'home rule' parliament in Dublin) and Unionists (who opposed this and hoped to exclude mainly-Protestant counties in Ulster from its authority).

${ }^{10}$ Herbert Henry Asquith (1852-1928), Liberal Prime Minister, 1908-16.

${ }^{11}$ In 1913 Asquith had built 'The Wharf' at Sutton Courtenay, about six miles from Nuneham.

${ }^{12}$ The Amending Bill proposed to ease tensions by excluding Ulster temporarily from the operation of Home Rule. Controversially, it did not limit how long the exclusion would be.

${ }^{13}$ John Redmond (1856-1918), leader of the Irish Nationalist Party, 1900-18.

${ }^{14}$ In the December 1910 election, the Liberal Party (272 seats) was only marginally ahead of the opposition Conservatives, then known as Unionists (271 seats). The Government could generally rely on support in the House of Commons from the Irish Nationalists (74 seats) and Labour Party (42 seats), but the Amending Bill threatened to upset this.
} 
I impressed on the P.M. that we must accept no conditions from the King which entail a Dissolution ${ }^{15}$. He professed to agree - but I doubt his conviction - and he sd. that if the King offered to assent to the H[ome].R[ule]. Bill with an immediate dissolution after, and we resisted and were dismissed, he thought the King wd. win at the Election.

I sd. I would sooner go to the country dismissed but with our Party intact than retain office with our party shattered and defeat by them certain.

We talked about the probable Austro-Servian War (Austria has refused the Servian reply ${ }^{16}$ ) and I told him that under no circs. could I be a party to our participation in a European War.'

I warned him that he ought to order Churchill ${ }^{17}$ to move no ship anywhere without instructions from the Cabinet. I have a profound distrust of Winston's judgement \& loyalty \& I believe that if the German fleet moved out into the Channel (agst. France - not us) he would be capable of launching our fleet at them without reference to the Cabinet.

The P.M. poohpoohed the idea - but I think he is wrong not to take this precaution.'

\section{July, Political Journal}

'Cabinet today at $\mathrm{H}$ [ouse] of $\mathrm{C}[\mathrm{ommons}]$. at 5.30.

We discussed in desultory way the Dublin gun-running \& firing by soldiers there yesterday. It appears the firing was done by privates on their own initiative without orders.

\footnotetext{
${ }^{15}$ That is, a dissolution of parliament, leading to a general election. It was widely expected that the Conservatives would win such an election.

${ }^{16}$ On 23 July, almost a month since the death of Archduke Franz Ferdinand, the Austro-Hungarian government made a number of harsh demands on Serbia, who it held responsible for his assassination. When, on 25 July, the Serbs refused to accept all the demands, the Austrians broke off diplomatic relations.

${ }^{17}$ Winston Churchill (1874-1965), First Lord of the Admiralty, 1911-15.
} 
Harrell (Asst. Comm. Of Police) who was sent for to Castle to receive orders did not go there, but went straight to military whom he called out on his own authority. He has been suspended this morning. ${ }^{18}$

Nationalist Party cd. think of nothing else today at their Party meeting (\& move the adjournment of the House on the subject at 8.15 tonight) so we have postponed the Amending Bill from tomorrow.

Birrell ${ }^{19}$ thinks they will agree to our proposal to drop the time limit for exclusion out of our Bill.

Then we discussed the Austro-Servian crisis. It looks as if war there was certain. But will Russia come in: followed by Germany \& France. ${ }^{20}$

Churchill met Ballin ${ }^{21}$ at Cassel's ${ }^{22}$ last night and B. asked Churchill if England wd. remain neutral if Germany promised when she defeated France to take no French soil but only some of her Colonies!

I said it was inconceivable that we should take part in a European War on a Servian issue, but still more inconceivable that we should base our abstention on such a bargain.

Grey $^{23}$ is working hard for peace and not belligerent - but L1[oyd]. Geo[rge]. ${ }^{24}$ is!

After the Cabinet I had talks with several colleagues in order to form a Peace Party which if necessary shall break up the Cabinet in the interest of our abstention.

\footnotetext{
${ }^{18}$ On 26 July the nationalist Irish Volunteers, smuggled in a delivery of German rifles via Howth, near Dublin. The authorities learnt this and William Harrel, Assistant Commissioner of the Dublin Metropolitan Police, called on the military for support. When returning to barracks, troops fired on a crowd who were heckling them. Four civilians were killed.

${ }^{19}$ Augustine Birrell (1850-1933), Chief Secretary for Ireland, 1907-16.

${ }^{20}$ Russia was sympathetic to Serbia in its dispute with Austria; Germany was allied to Austria-Hungary in the Dual Alliance since 1874; France was allied to Russia since 1894.

${ }^{21}$ Albert Ballin (1857-1918), chair of the Hamburg-America shipping line, with links to the German government.

${ }^{22}$ Sir Ernest Cassel (1852-1921), German-born financier and naturalised British subject; made a Privy Councillor, 1902.

${ }^{23}$ Sir Edward Grey (1862-1933), Foreign Secretary, 1905-16.

${ }^{24}$ David Lloyd George (1863-1945), Chancellor of the Exchequer, 1908-15.
} 
I think I can already count on 11.

Self, J. Morley ${ }^{25}$, Runciman ${ }^{26}$, McK. Wood ${ }^{27}$, Pease $^{28}$, McKenna $^{29}$, Beauchamp ${ }^{30}$,

Burns $^{31}$, Simon ${ }^{32}$, Hobhouse ${ }^{33}$, Birrell (probably also Samuel ${ }^{34}$ and Masterman ${ }^{35}$ ).

If we destroyed this Govt. to prevent war, no other cd make it.

It is said the first shots have been fired this afternoon by Servia on Austria., ${ }^{36}$

\section{July, Political Journal}

'Cabinet today at 10 D. St. $11.30 \quad 29.7 .14$

Grey late - with German Ambassador ${ }^{37}$.

Churchill (with P.M.'s assent yesterday) has removed all gunboats etc. patrolling Irish coast against arms - as boats are wanted with fleet in North Sea owing to possible

War. This will allow arms to go freely into Ireland as Customs Officers will stop only small quantity.

We discussed shortly an idea of turning both Ulster and Nat[ionalist]. Volunteers into Territorials $^{38}$ This wd. require an amendmt. of the Territorial Act. We regarded it favourably - but the time is not yet. Redmond said it wd. be welcomed in Ireland. Dougherty $^{39}$ (Under-Secy. for Ireland) is now 70 \& useless - willing to go - we propose to appoint in his place Sir Matt. Nathan ${ }^{40}$ of the Inland Rev[enue].

\footnotetext{
${ }^{25}$ John Morley (1838-1923), created Viscount Morley in 1908, Lord President of the Council, 1910-14.

${ }^{26}$ Walter Runciman (1870-1949), President of the Board of Agriculture, 1911-14.

27 Thomas McKinnon Wood (1855-1927), Secretary of State for Scotland, 1912-16.

${ }^{28}$ Joseph Albert Pease (1860-1943), President of the Board of Education, 1911-15.

${ }^{29}$ Reginald McKenna (1863-1943), Home Secretary, 1911-15.

${ }^{30}$ William Lygon, $7^{\text {th }}$ Earl Beauchamp (1872-1938), First Commissioner of Works, 1910-14.

${ }^{31}$ John Burns (1858-1943), President of the Board of Trade, February-August 1914.

32 John Simon (1873-1954), Attorney-General, 1913-15.

${ }^{33}$ Charles Hobhouse (1862-1941), Postmaster-General, 1914-15.

${ }^{34}$ Herbert Samuel (1870-1963), President of the Local Government Board, 1914-15.

${ }^{35}$ Charles Masterman (1873-1927), Chancellor of the Duchy of Lancaster, 1914-15.

${ }^{36}$ Austria actually declared war on Serbia on 28 July.

${ }^{37}$ Prince Max Lichnowsky (1860-1928), Ambassador to London, 1912-14.

${ }^{38}$ Members of the Territorial Army, a volunteer army reserve created in 1908.

${ }^{39}$ Sir James Brown Dougherty (1844-1934), Under-Secretary for Ireland, 1908-14.
} 
For the Commission to enquire into the recent affray in Dublin on landing arms we shall appoint Ld. Shaw of Dunfermline ${ }^{41}$ if he will go.

Grey arrived $1 / 2$ hour late.

European situat. very bad. - Austria declines to continue communications by her Ambassador at St Petersburg. Russia has sd. she will mobilise if Austria declares war - before end of Cab. we heard Russia had mobilised in cert. towns on her southern frontier. Germany has sd. she will not mobilise unless Russia does so on her (Russia's) Western frontier.

We discussed our liabilities for the guarantee of Belgian neutrality \& independence which rests on the European treaty of 1839.

Is it a joint or several guarantee? Are we bound to observe it if other parties do not? Is it an undertaking to Belgium? If so what are we to do if Belgium does not ask or wish for our action.

Law Officers in '[18]70 thought it was a several guarantee \& hence Anglo-French \& Anglo-German treaties of that year declaring its neutrality. ${ }^{42}$

Everyone agreed we should not land troops in Belgium. France might want us to do so on the French side of Belgian frontier.

McKenna sd. we cd. more effectively deal with German aggression on Belgium by our fleet sealing up German ocean traffic. In first few weeks of war all German railways wd. be in use for troops \& not available for ordinary food supplies.

\footnotetext{
${ }^{40}$ Sir Matthew Nathan (1862-1939), Chairman of the Inland Revenue, 1911-14; Under-Secretary for Ireland, 1914-16.

${ }^{41}$ Thomas Shaw (1850-1937), Scottish lawyer; Liberal MP, 1892-1909; created Baron Shaw, 1909.

${ }^{42}$ During the Franco-Prussian War, London secured guarantees from both sides that they would not infringe the 1839 guarantee of Belgian neutrality, given by Europe's great powers (Britain, France, Germany, Austria and Russia). In 1914, it was expected Germany would use Belgium as an invasion route into France, though the direction and scale of such an operation were uncertain.
} 
We might try to make with France \& Germany similar agreements to those of '70 for our neutrality if Belgian territory not violated, but this wd. be notice to Germany of our non participation - \& regarded at this moment by France as an unfriendly act Russia says we can prevent Europ. War by saying we shall support France - German says we can prevent it by saying we shall not do so.

Grey is afraid that at any moment France may ask us if we mean to stand by her. This of course cannot be answered without a Cabinet decision: we do not decide that today: new circs. may arise.

(I am determined not to remain in the Cab. if they decide to join in a war - but they cannot so decide as I am certain now I can take at least 9 colleagues out with me on resignation, viz. Morley, Burns, Beauchamp, McK Wood, Pease, Samuel, Hobhouse, Runciman, Simon ${ }^{43}$ )

L1. Geo. \& Winston less bellicose today than at our last meeting.

Grey does not believe that our action wd. be a real deciding element in the outbreak (or not) of war.

Reuters ${ }^{44}$ have just informed Grey that the opinion in Berlin is that our intervention wd. be too late (to prevent them using the Belgian route?)

Sazanoff $^{45}$ (Russian For. Min.) says if we want to stop Russia joining we must stop the Austrian advance on Servia - that is impossible.

Churchill has moved all his ships to their war stations in the North Sea. Crews are recalled Forts being manned - magazines \& oil stores guarded. The "Precautionary Stage" ${ }^{\not 6}$ has been reach [sic] and the appropriate telegrams sent everywhere. I send

\footnotetext{
${ }^{43}$ Note that the number of ministers likely to resign had declined from the 11-13 of 27 July: Birrell, Masterman, McKenna and Pease are no longer listed, but Samuel, previously a 'probable', has become a definite supporter of Harcourt.

${ }^{44}$ London-based news agency, known for being first to report foreign news.

${ }^{45}$ Sergei Sazonov (1860-1927), Russian foreign minister, 1910-16.

${ }^{46}$ Designed to prepare the British government and Empire for possible war.
} 
mine to all Col[onie]s. and Domin[ion]s. at 6 tonight. No search of ships in port to be made at present.

Grey proposes to see the German \& French Ambass[adors]. this afternoon and to say to the German "you must not assume that we shall not join France" and to the French ${ }^{47}$ "you must not assume that we shall join you"

This is a sound strong \& honest Diplomatic position so long as we in Cabinet do not commit ourselves to a decision. When (and if) we do, Grey's position will be hopelessly weakened.

Gen. Macready ${ }^{48}$ has been again to Belfast: he says if the Provisional Govt. it will do nothing \& seize nothing and can properly be neglected.

The Amending Bill $2^{\text {nd }} \mathrm{R}$. is to be taken tomorrow. The Irish Nat. have reluctantly agreed to our dropping the time limit and giving the County option.

Went over to C[olonial].O[ffice]. (after luncheon at 10 Downing St.) and ordered "Precautionary" telegrams to be sent to all Colonies and Dominions.

European situation getting worse tonight.

Up till 2 a.m. in H of C. carrying Report \& $3^{\text {rd }}$ reading of my Nationality Bill ${ }^{49}$.

McKenna has had long talk with Ll.Geo. Ll.G. is now is now [sic] in full flight to us (Peace party) got ear to ground, finds public opin. strong against war and wants to be with it: even wanting to make speech in that sense: God forbid, it wd. cause war.

Winston also less bellicose, also wants to be on popular side.

Gives me impression of man who has looked over precipice \& drawn back, but these popularity hunters not to be trusted. We who don't care for public opinion must act when these men are wobbling back to war as they will be in a few days.

\footnotetext{
${ }^{47}$ Paul Cambon (1843-1924), Ambassador to London, 1898-1920.

${ }^{48}$ Major-General Sir Nevil Macready (1862-1947), General Officer Commanding, Belfast, 1914.

${ }^{49}$ The British Nationality and Status of Aliens Act, 1914.
} 
McKenna thinks the P.M. does not mean to go into war as long as he is at the War Office. $^{, 50}$

\section{July, Political Journal}

'Heard this morn that "search" of ships had been made at Gib[raltar]. last night. Sent for copies of telegrams from Adm[iralty]. to Gib. \& Malta sent yesterday. They were correct \& warned that search was not to be commenced.

Sent special fresh warnings by tel. to all Domins. \& Cols. to prevent search - am much afraid of an "incident" over search on some German vessel.

Lambert ${ }^{51}$ of Admlty told me Churchill last night hired "Acquitania"52 (Cunard)?

What for? Transport of troops to Belgium or for guard ship in Mersey? Also commandeered all coal in South Wales - Cardiff paralysed; he is sd. to have incurred expenditure of over $£ 1,000,000$ - he told us at Cab. yesterday "Precautionary" stage expenses wd not exceed $£ 10,000$. I think he has gone mad. Every room in Admiralty lighted and men at work when I passed at 2 a.m. this morning. I fear he is carrying his preparation too far and getting prematurely in the war stage.

Had Ld. Gladstone ${ }^{53}$ \& Ld. Buxton ${ }^{54}$ at C.O. from 11-1.30 this morn. discussing S. Afr[ican]. Affairs. Told them of my settlement with B.S.A. Co ${ }^{55}$, over Charter which I shall announce next week.

Lunch at H of C. with Samuel \& Birrell.

\footnotetext{
${ }^{50}$ In addition to being Prime Minister, Asquith took the role of Secretary of War between March and August 1914.

${ }^{51}$ Probably George Lambert (1866-1958), Civil Lord of the Admiralty, 1905-15; but possibly RearAdmiral Sir Cecil Lambert (1864-1928), Fourth Sea Lord, 1913-16.

${ }^{52}$ RMS Aquitania, a Cunard ocean liner, launched 1913, used as a naval vessel during the First World War.

${ }^{53}$ Herbert, $1^{\text {st }}$ Viscount Gladstone (1854-1930), son of premier William Gladstone; Governor of South Africa, 1910-14.

${ }^{54}$ Sydney Buxton, $1^{\text {st }}$ Earl Buxton (1853-1934), formerly a Liberal Cabinet minister, appointed to succeed Gladstone as Governor of South Africa.

${ }^{55}$ British South Africa Company, first chartered 1889, exploited minerals and other resources.
} 
$2^{\text {nd }} R$. of Amending Bill for today to be postponed (at suggestion of B. Law ${ }^{56} \&$ Carson ${ }^{57}$ ) in order to show Europe "solid front" of country in present continental crisis. (So announced by Asquith in $\mathrm{H}$ of C. at 4 p.m.)

On Front Bench at Question Time Grey told me he had recd. from Bethmann Hollweg $^{58}$ (I suppose thro' Goschen ${ }^{59}$ at Berlin) shameful proposal that we should declare our neutrality on promise from Germ. Govt. that they wd. respect neutrality of Holland: ditto of Belgium after they had violated it to attack France; wd. not, after crushing France, annex European territories (tho' take her Colonies): subsequently offer us a European neutrality \& friendship in general affairs. Grey of course without hesitation rejected offer with (I think) some contumely.

Cambon (Fr. Ambass.) is coming this aft. to Grey to put the question "are we going to help France if war breaks out." Grey told me he will say to Cambon "I cannot answer without a Cabinet (tomorrow morning) but tell him that in pres. circs. public opinion here not support or enable H[is]. M[ajesty's]. G[overnment]. to give an affirmative answer."

Cambon if wise will accept non-committal answer sooner than negative.

Simon, J. Morley, Hobhouse, Beauchamp, Pease, Runciman, Montagu ${ }^{60}$, Birrell all been in my room this afternoon - all with me, but Hobhouse with some reservations as to Belgium (he was of course a soldier). Jellicoe $^{61}$ takes command of Channel Fleet today.

\footnotetext{
${ }^{56}$ Andrew Bonar Law (1858-1923), leader of the Conservative Party, 1911-21 and 1922-23; Prime Minister, 1922-23.

${ }^{57}$ Edward Carson (1854-1935), leader of the Irish and Ulster Unionists, 1910-21.

${ }^{58}$ Theobald von Bethmann-Hollweg (1856-1921), Chancellor of Germany, 1909-17.

${ }^{59}$ Sir Edward Goschen (1847-1924), Ambassador to Berlin, 1908-14.

${ }^{60}$ Edwin Montagu (1879-1924), Financial Secretary to the Treasury, 1914-15.

${ }^{61}$ John Jellicoe (1859-1935), Second Sea Lord, 1912-14; made Commander-in-Chief of the Home Fleet on 4 August 1914.
} 
I sent Sir H. Miles ${ }^{62}$ (Govr. of Gib.) back to his post today - pledged on word of honour to avoid any "incident"

Simon sd. to me pointing to Pease "my views are those of his forebears"63.

Lambert tells me Winston's mad commandeering of coal has been cancelled this afternoon.

My prescribed duty in "precautionary stage" to ask Australia to place her fleet at our disposal \& put under command of Admiralty.

I declined to send this tel. this morn. on ground premature, unnecessary and that I wanted initiative to be taken by Australia - if initiative failed I would tel (priv. and pers.) to R.M. Ferguson ${ }^{64}$ to try to produce it. At 5 p.m. recd. acknlgmt. fr. Austral. of my "warning" tel. with unofficial offer of their fleet for our purposes.

Sent tel. to Admlty and P.M. - Admlty asked me to tel. to Austr. for fleet to go to "War stations". I did so with regret (cd. not take responsibil. of refusing) - think premature, but possibly justified on ground of great distances for their fleet e.g. The Australia $^{65}$ has got to go to coast of West. Australia.

Hobhouse hears from Pres. of Dresdener Bank that Germany has given Russia 24 hours to explain her mobilisation, failing which Germany will mobilise.

Emmott $^{66}$ and Vernon ${ }^{67}$ (of C.O.) came to me this morn. to say French delegates to New Hebrides Commiss. must return to France on Sat. (convinced War will be declared by Monday) and Commiss. must meet at 10 a.m. tomorrow morn to conclude report etc. $^{68}$

\footnotetext{
${ }^{62}$ Sir Herbert Miles (1850-1926), Governor of Gibraltar, 1913-19.

${ }^{63}$ Pease was a Quaker.

${ }^{64}$ Ronald Munro Ferguson (1860-1934), Governor-General of Australia, 1914-20.

${ }^{65}$ HMAS Australia, launched 1911, flagship of the Royal Australian Navy in 1914.

${ }^{66}$ Alfred Emmott (1858-1926), Under-Secretary of State for the Colonies, 1911-14.

${ }^{67}$ Roland Venable Vernon (1877-1942), civil servant in the Colonial Office, 1900-14 and 1921-37.

${ }^{68}$ The New Hebrides (now Vanuatu) was jointly administered by Britain and France after 1908; in 1914 the administrative arrangements of the Condominium were renegotiated.
} 
Important decision as to imported labour ought to be a Cabinet decision: impossible to ask Grey \& Asquith \& Cabinet to consider at this moment.

Told Asq. at Cab. yesterday. He said "I have complete confidence in you - decide as you think best." I have given Emmott his instructions.

J. Morley told me this aft. he was prepared to resign at my signal, but I don't think it will be tomorrow.

Ld. Bryce ${ }^{69}$ has been to me - and separately Molteno ${ }^{70}$ M.P. on behalf of Radicals to ask situation. Both sd. they were confident in me and as long as I stayed in Cabinet they wd. assume that peace was assured. I am to let them know if that situation alters.' War situation I fear much worse tonight. Pray God I can still smash our Cabinet before they can commit the crime.'

\section{Also filed with the 30 July entry, on Downing Street headed paper:}

\section{First Note}

Harcourt to Simon: 'L.G. is now entirely with us! L.H.'

Simon to Harcourt: 'I was with him last night and at breakfast this morning and he got business view of Manchester as well as other centres - all same view.'

\section{Second Note}

Harcourt to Pease: 'Tell Samuel what we decided this morning \& ask him if he agrees, Birrell has joined us.'

Pease to Harcourt: 'I have - and I regard him as taking the view - peace unless we are menaced - but he thinks the German Fleet might sail down the Channel to attack French colonies.'

\footnotetext{
${ }^{69}$ James Bryce (1838-1922), former Liberal Cabinet minister; Ambassador to Washington, 1907-13; created Viscount Bryce in 1914.

${ }^{70}$ Percy Molteno (1861-1937), Liberal M.P., 1906-18; had opposed the Boer War.
} 


\section{July, Political Journal}

'Cab. 11.0 10 D. St. 31.7.14

(Stock Exchange closed this morn. till further notice ${ }^{71}$ )

Grey saw Cambon yesterday - told him he cd. not answer about our support to France till he had consulted Cab. today.

Proposes to tell him this afternoon that present Engl. opinion wd. not support our participation. If Belgium violated, might change public opin. but in any case we could never promise assistance without assent of $\mathrm{H}$ of Commons e.g. vote of credit $^{72} \mathrm{wd}$. be necessary.

Grey reported monstrous proposal of Bethmann Hollweg of yesterday that we shd. declare neutrality on promise that Germany wd. not violate neutrality of Holland now and guarantee neutrality of Belgium after the war! If was successful French territory not to be annexed but this not to apply to Fr. colonies, \& an offer of some permanent German neutrality afterwards.

Grey refused this at once in an admirable telegram (approved before sent by Asq \&

\section{Ll.Geo.)}

A Ponsonby ${ }^{73}$ M.P. wants to put quest. to P.M. in H of C. at 12 today asking for promise that we not commit country to war without consulting H of C. Grey saw Ponsonby last night $\&$ told him that we have made no promises $\&$ use no "threats" to anyone. Grey is inclined to give the answer A.P. wants, but not till Monday. Some colleagues rather unwilling - others sd 'it amounts to nothing.' I pressed answer should be given as it helps our Peace friends to keep quiet - most important they

\footnotetext{
${ }^{71}$ The closure of the London Stock Exchange reflected the financial crisis that threatened as war approached. It was followed by an increase in the Bank Rate (which affected interest rates in general) from $3 \%$ to $4 \%$ on 30 July, to $8 \%$ on 31 July (its highest level since 1873 ) and $10 \%$ on 1 August.

${ }^{72}$ To approve war expenditure.

${ }^{73}$ Arthur Ponsonby (1871-1946), Liberal MP, 1908-18; Chair of the party's backbench Foreign Affairs Group.
} 
should do so and we in Cab. still remain uncommitted so as to strengthen Grey's hands diplomatically. A.P. asked to postpone till Monday when Asq. will probably give him the answer.

Ll.Geo. has been (at Asq's request) exploring mercantile \& business opinion on our participation in war. L1.Geo. now hotly \& earnestly on our (Peace) side. Gov. of Bank of England ${ }^{74} \&$ all city opinion aghast at any possibility of our being dragged in. Business men in North say if we were all mills factorys [sic] mines, shipping etc. stopped. Wholesale unemployment, population starving because no wages to buy food. One man sd. to him, “they won't be able to buy food but they will get it "England will be in revolution in a week"

Ll.G. very eloquent agst. our participation \& impressed Cabinet - but as he depends on public opin. he may wobble over again in 2 days.

(We recurred to Greys prospective talk with Cambon this afternoon and Grey sd. definitely that he wd. make no promises as to our action in hypothetical circs.) I feel now that this Cabinet will never join in this war - though several colleagues are uneasy on the subject of our treaty obligations about Belgium.

The situation seems distinctly better this morning as yesterday Vienna and St. Petersburg “began talking again” (Grey’s words).

J. Burns says Prince Henry of Prussia ${ }^{75}$ left by spec. train last night for Petersburg with letter from Kaiser to Czar.

Grey proposes in talking to Lichnowsky today to suggest that Berlin should get Vienna to make some reasonable offer to St. Petersburg and then if Russia proved unreasonable it might give us ground to wash our hands of Russia or to secure Russian acceptance of offer.

\footnotetext{
${ }^{74}$ Walter Cunliffe (1855-1920), Governor, 1913-18.

${ }^{75}$ Henry (1862-1929), brother of Kaiser William II.
} 
I told Cab. that immediately on receipt of my warning telegram Australia placed her fleet at our disposal \& last night at Admlty wish I asked them to send their fleet to Australian war stations - the "Australia" Dreadnought to go to coast of West. Austr. $\&$ ready to proceed to Hong Kong.

Churchill wants to bring into immediate operation a C[ommittee of].I[mperial]. $\mathrm{D}$ [efence]. ${ }^{76}$ plan (by Huth Jackson ${ }^{77}$ ) for national war shipping risk insurance (mercantile) which might cost Treasury $£ 27,000,000 .{ }^{78}$ Cabinet (not membs. of C.I.D.) never heard of this \& wd. not adopt it blindfold.

Asq. and I also agst. immediate adoption.

Winston very angry - overwrought $\&$ excitable.

(I hear that the hiring of Acquitania \& commandeering of S.W. coal was a "happy inspiration" on Wed. night after dinner, but that he cancelled both yesterday morning) Redmond has suggested (\& P.M. inclined to accept) that H.R. Bill should become law now - Amending Bill to be dropped until winter session but pledge given that H.R. Bill should not be brought into operation until an Amending Bill has been "disposed of". Redmond says that with the H.R. Bill on the Statute Bk he would be able to make much larger concessions than now (perhaps all the 6 counties). I feel that Ulster cd. never agree to this and must set up Provisional Govt. at once.

Asq. met B Law \& Carson in someone else's house on Tues. to agree to the postponement on that day of the Amending Bill and Carson sd. he thought that if the lge no. of Brit. reserve officers now in the Ulster Volunteers were called up to rejoin on War they wd. decline to leave Ulster! We suppose he thought this might intimidate

\footnotetext{
${ }^{76}$ The Committee of Imperial Defence, established in 1902, included army and navy representatives, civil servants and Cabinet ministers.

${ }^{77}$ Frederick Huth Jackson (1863-1921), merchant banker and a Director of the Bank of England. In 1913-14, chaired a CID sub-committee, investigation into the provision of shipping insurance in war.

${ }^{78}$ The war crisis had pushed up premiums for shipping insurance over recent days. It was vital for the UK, as an island power, to maintain trade. On 4 August the Government undertook to cover 80 percent of insured shipping losses suffered as a result of the War.
} 
Asq. which it did not. It wd. destroy the public respect for the "loyal"! volunteers \& all true officers wd. be liable as deserters during war to be shot!!

It wd. be almost worthwhile to call up the reserves in order to exhibit such a situation!!

Cabinet rose at 1 p.m. Asq. told us we must not go far from London - i.e. I might go to Nuneham, but Samuel not to Yorkshire.

4 p.m. H of C.

Situation suddenly much worse since morning. Russia mobilise whole army \& navy. Germany declared herself to be "in a state of War" $" 79$ viz. under martial/military law and we assume she immediately mobilises. Either she or France may strike tonight. (May ${ }^{80}$ and I given up going to Nuneham)

Bank rate put at $8 \%$ this afternoon - considerable run on Banks for gold from depositors.

P.M. from 3.15 to 4 with King.

Then saw Gov. of Bk of England (likewise he wanted immediate suspension of Bank Act $^{81} \&$ that Asq. refused.)

I told Bonar Law \& Chaplin ${ }^{82}$ the Russian \& German news. B. Law in relation to gt. rise in corn \& flour prices suggested to Runciman \& me that the Govt. should make gt. purchases of corn \& sell at true prices to millers \& bakers to prevent gambling \& cornering pressure \& prices.'

\section{Also filed with the 31 July entry are two notes, on Downing Street headed paper.}

\footnotetext{
${ }^{79}$ The Kaiser had declared the Kriegsgefahrzustand, a situation of imminent danger of war.

${ }^{80}$ Mary Ethel Burns, niece of American millionaire banker J.P. Morgan, married Harcourt in 1899.

${ }^{81}$ The 1844 Bank Charter Act was suspended in earlier financial crises, most recently in 1866 . This allowed the Bank of England to exceed established limits on its issuance of notes, so as to maintain liquidity in the economy. In the event, though suspension was widely predicted, it proved unnecessary. ${ }^{82}$ Henry Chaplin (1840-1923), Conservative M.P. and former Cabinet minister.
} 


\section{First Note}

Harcourt to Pease: 'This is going well so far'

Pease to Harcourt: 'I can't stand our being now committed (to be drawn into war) by saying what we will do in hypothetical circumstances.'

Harcourt to Pease: 'But Grey is not proposing to commit us to any hypothetical position.'

Pease to Harcourt: 'I thought so in reply to Cambon's question.'

\section{Second Note}

Simon to Harcourt: 'One large consideration not mentioned today is the importance of Great Britain being in a position in the latter stages of a European war (1) to mediate as a friend all round (2) to re-establish European finance.'

Harcourt to Simon: 'I think our abstention is vital but I don't think as a result anyone will regard us as a friend.'

\section{August, Notes of Cabinet meeting}

'Cab. 1.8.14

Germany short of 30-40\% wheat supply.

L[or]d. Chanc[ellor]. ${ }^{83}$ long essay on situation towards preparations, \& tell

Lichnowsky feeling about Belgium “deciding factor”, but promise our neutrality if Fr. not invaded.

Grey not committed to Cambon.

2 Brit. ships (G[rea]t. Cent[ral]. Rly.) held up at Hamburg. ${ }^{84}$

Letter F.E. Smith ${ }^{85}$ to Winston, support of Opposition on Belgium.

\footnotetext{
${ }^{83}$ Richard Haldane (1856-1928), Lord Chancellor, 1912-15 and 1924; formerly Secretary for War, 1905-12.

${ }^{84}$ The Great Central Railway ran a shipping service to Hamburg. Three of its ships were seized there at the end of July: the 'City of Bradford', 'City of Leeds' and 'Bury'. The three were renamed for service in the German navy during the war, but restored to the GCR afterwards.
} 
Churchill wants mobilise the whole Navy: very violent.

Asq. sd. no proclamation before Monday

Grey supports Churchill - no proclamation today.

Ll.G. - food supply: moratorium ${ }^{86}: £ 1$ notes: insurance.

I to be on the "Finance Committee" $" 87$

The Turkish Dreadnought ${ }^{88}$ just built here not to be allowed to leave.

German Emperor's message. Belgian telegrams

Italian neutrality ${ }^{89}$ : suspend Bank Act (specie ${ }^{90}$ payment)?

Grey two alternatives (no obligation)

Ll.G. intervenes later (our men on Meuse ${ }^{91}$ )

Long speech by Winston on tactics.

Reply by Ll.Geo.'

\section{August, Notes of meeting of the Finance Committee}

'Cab. Comm. 2 p.m. 1.8.14 B[oar]d. r[oo]m. Treasury

Ll.Geo., Haldane, Samuel, McKenna, Runciman, Simon, Montagu, self, Emmott.

Gov. \& Deputy Gov. of Bank ${ }^{92}$, Sir F. Schuster ${ }^{93}$, L. Currie ${ }^{94}$, Sir E. Holden ${ }^{95}$, \& 5 or

6 others

\footnotetext{
${ }^{85}$ Frederick Edwin Smith (1872-1930), barrister, Conservative M.P. and member of the opposition front bench; a close friend of Churchill, despite their political differences over Ireland.

${ }^{86}$ The Chancellor evidently raised the possibility of a moratorium on debt payments to ease financial pressures, as well as the issuance of new low-denomination banknotes.

87 This ministerial committee, set up to manage the financial crisis, met for the first time in the afternoon: see Harcourt's note below.

${ }^{88}$ In fact, two dreadnoughts were being constructed in British shipyards for Turkey, but the Sultan Osman was nearest to completion. Both ships were seized, on Churchill's orders, and fought in the Royal Navy during the war.

${ }^{89}$ Italy, nominally an ally of Germany and Austria-Hungary, declared its neutrality on 2 August 1914. In May 1915, it entered the war on the Allied side.

${ }^{90}$ That is, payments in coin form. With the Bank of England legally obliged to exchange banknotes into gold coin, its coin stocks were falling rapidly. But the Bank itself resisted calls to suspend specie payment, fearing such a step would undermine confidence in the economy.

91 The River Meuse flows through France, Belgium and the Netherlands. In 1914, it seemed likely the British Expeditionary Force might advance towards it but, in the event, the German army rapidly crossed the river.
} 
We told them we had decided on a Moratorium Bill for Monday ${ }^{96}$ (H of C. and L. to suspend all Stand[ing]. Ord[er] $\mathrm{s}^{97}$ )

Schuster says we must have a Moratorium for all classes.

Bankers also want to be allowed to deposit $£ 15$ mills Gold and $£ 30$ mills. of securities in Bank of England and to receive $£ 45$ mills. of notes in exchange. ${ }^{98}$

We made the arrangement terminable with the Moratorium. The Bk of England were very obstinate. ${ }^{99}$

We shall have to suspend all Standing Orders on Monday in the $\mathrm{H}$ of C. to get a Moratorium Bill - we are now 6.15 discussing the details of this.

The Admlty now wish the "examination" of all ships in defended ports to take place. I consulted the P.M. and he thinks the time has come. So I send my telegrams to Cols \& Dominions.

7 p.m. We are now discussing state insurance of shipping war notes.'

[NB the lines reflect those written across the page in pen by Harcourt.]

\footnotetext{
${ }^{92}$ Sir Robert Newman (1871-1945), wine merchant; later a Conservative MP; Deputy Governor 191315.

${ }^{93}$ Sir Felix Schuster (1854-1936), German-born banker and a naturalised British subject; chair of the Central Association of Bankers, 1913-15.

${ }^{94}$ Lawrence Currie (1863-1934), Managing Partner of Glyn, Mills, Currie and Co., a private bank.

${ }^{95}$ Sir Edward Holden (1848-1919), Liberal MP, 1906-10; chair of the UK's largest bank, the Midlan Bank, 1908-19.

${ }^{96}$ A one-month moratorium on payments of bills of exchange, apart from cheques, was introduced on 3 August. This relieved financial pressure on Accepting Houses in the City of London, who faced insolvency thanks to the panic withdrawal of funds.

${ }^{97}$ The written procedures governing the business of each House had to be suspended to allow emergency legislation to pass swiftly.

${ }^{98}$ On 31 July, in an attempt to deal with the current financial crisis, Schuster and Holden had written to the Bank of England, proposing that British bankers would deposit gold and securities at the Bank, in return for the issue of an emergency currency. This scheme was opposed by the Bank of England, which accused the High Street banks of 'hoarding' gold.

${ }^{99}$ By now, relations between the Bank of England and High Street banks were very strained, with Cunliffe blaming the bankers for contributing to the financial crisis, rather than helping to solve it.
} 


\section{Separate Note by Harcourt, 1 August, written on Downing Street headed paper}

'I must resign today if there is any decision to take part automatically under certain circs. without previous reference to the Cabinet.'

[Below this is written, evidently by Beauchamp, Birrell or Burns:]

'There will be nothing of the kind. B.'

\section{August}

'Sunday $\quad 2.8 .14$

Simon \& Illingworth ${ }^{100}$ came to me at $14 \mathrm{~B}$ [erkeley]. Sq[uare] at midnight last night to ask me to come to Ll.Geo. at 11 Down. St. at 10 this morn. I suggested other Peace colleagues.

Went there at 10. We had Pease, McK. Wood, Beauchamp, Simon, Runciman, Ll.Geo. and self.

Settled we wd. not go to war for mere violation of Belgian territory \& hold up if possible any decision today.

11.0 a.m. Before Cab. L1.Geo. and I went to P.M. \& sd. we represented 8-10 colleagues who wd. not go to war for Belgium. P.M. listened, sd. nothing. Birrell added his name to others before Ll.G. and I went up.

At Cabinet 11-1.55

Moratorium Bill approved. - ditto arrangts. with Priv. Banks \& Bk of Engl. as to deposit of $£ 15$ mills of gold \& 35 mills. securities \& issue of notes agst. both.

${ }^{100}$ Percy Illingworth (1869-1915), Parliamentary Secretary to the Treasury (that is, Government Chief Whip), 1912-15. 
Issue of $£ 1$ and 10/- [shilling] Bk notes will take at least 3 weeks: in mean time we can make Postal notes legal tender: we have $£ 2,500,000$ in stock and can get $£ 500,000$ per diem.

War risk sea insurance (Huth Jackson's scheme) approved.

War is declar. by Germany on Russia.

Luxemburg is invaded by Germans - Duchy has protested to us. ${ }^{101}$ Germ. troops are moving south as if they did not mean to enter Belgium.

The Germ. Ambass. saw P.M. this morning - he was in tears \& sd. it is not France but my country wh. is going to be crushed - he thinks his Govt. mad.

Grey saw the Fr. ambass. yesterday - he also in tears. Grey told him we shd. not send troops to France to defend the Franco-Belg. frontier (this now less necess. as Italy has declared her neutrality \& thus releases 6 divs. of Fr. troops fr. the Ital. frontier).

Grey also told Cambon that we took yesterday no decis. as to Belgian neutrality or as to our action if Germ. fleet came into Channel.

But Grey sd. it was vital to him that he shd. today assure Cambon that if the Germ.

Fleet attacked French Coast we wd. prevent it \& use all our naval power, and he must say this in Parlt. tomorrow.

Nothing is to be sd. today to Cambon (whom Grey sees at 2.30) as to our attitude to a breach of Belg. neutrality.

Grey is much stronger than before for joining in war and wd. like to promise France our help today.

Crewe ${ }^{102}$ from all he sd. this morning seems to be with "us".

\footnotetext{
${ }^{101}$ In the 1867 Treaty of London, Luxembourg was given an international guarantee of its neutrality and independence. But this was of a 'collective' nature, so that the signatories (Britain, France, Germany, Russia, Austria and Italy) were not individually obliged to enforce it. In this sense it differed from the 1839 guarantee of Belgian neutrality, which was ambiguously worded but could be interpreted as placing an individual obligation on the signatories.

102 Robert Crewe-Milnes, Marquess of Crewe (1858-1945), Leader of the House of Lords, 1908-16.
} 
Bonar Law wrote to P.M. during Cabinet that he \& Lansdowne ${ }^{103}$ as represent. Un[ionist]. Pty. are prepared to support Govt. in war \& think it "wd. be fatal to the honour and security of the U.K. to hesitate".

On Belg. neutrality Winston sd. 'If Germ. violates Belg. neutrality I want to go to war - if you don't I must resign.' J. Morley sd. 'If you do go to war I resign.'

$\mathrm{J}$ Morley very angry at Fleet reserves being mobilised during last night - contrary to Winston's promise to Cab. It still may not be necess. to issue Proclamation till tomorrow.

J. Burns sd. he could not agree to Grey's formula to Cambon this afternoon as to German fleet attack on Fr. coast and must resign at once - almost in tears. We all begged him to take time to think \& to come back to Cabinet at 6.30 this evening. $\mathrm{He}$ promised to do this.

At 2 p.m. I went to lunch with Beauchamp in Belgrave Sq. J. Morley, Simon, Samuel, Ll.Geo. also came. We telephoned for Pease, McK. Wood \& Runciman who joined us after luncheon \& discussed plans for afternoon. Beauchamp feels we were "jockeyed" this morning over Germ. fleet; Simon agrees \& thinks we ought to have resigned with Burns. I differ as I think the prevention of a German fleet attack \& capture of French territory on shore of Channel a British interest.

We agreed to refuse to go to war merely on a violation of Belg. neutrality by a traverse for invasion purposes of territory but to regard any permanent danger or threat to Belg. independence (such as occupation) as a vital Brit. interest.

Left Beauchamp's at $4 \&$ most of us met again at Ll. Geo's at 11 D[owning]. St. at 6 p.m. (Cabinet at 6.30) Nothing new at this meeting.

Cabinet $6.30-8$.

\footnotetext{
${ }^{103}$ Henry Petty-Fitzmaurice, Marquess of Lansdowne (1845-1927), a former Secretary for War and Foreign Secretary; Conservative leader in the House of Lords, 1905-16.
} 
Grey reported Cambon had taken his communication quietly \& had not pressed for further assurances about Belgium and grey does not press for a decision on this tonight.

Churchill has seen French naval attaché since this morning's Cab. \& told him our decision about Germ. fleet and arranged to open "the joint naval signal books". J. Morley very angry $-\mathrm{sd}$. attempt to create an alliance for war.

Grey sd. he would not inform Germany of our decision about her fleet in the Channel - she must learn this from the statement in $\mathrm{H}$ of $\mathrm{C}$. tomorrow. We (some) thought this a mistake but Asq. had told Lichnowsky this morn. that we should regard such action by Germ. very seriously.

It is clear now that the Germans have crossed the Fr. frontier thro' Luxemburg \& probably at Nancy.

The New Z[ealand]. govt. have offered an Expeditionary Force.

With P.M.'s concurrence I have thanked them but sd. no condition yet which renders this necessary.

Simon asked Churchill if any orders yet given to attack German fleet if they come out tonight. Churchill sd. definitely "no". I sd. it wd. be monstrous to attack them if they were coming out not agst. us and without having been informed of our decision.

J. Burns at end of Cab. sd. nothing had occurred to change his decision and he must resign tonight. P.M. asked him not to do so till he had had a talk with him. J.B. agreed but sd. he was immoveable. (P.M. told me he meant to postpone the talk till tomorrow morn)

Dined at home - housemaid, chop. 
At 10 p.m. got letter fr. Admlty suggesting a South African garrison \& guns shd. be put into Walfisch Bay in Germ. West. Afr. ${ }^{104}$

Found that P.M was dining at McKenna's \& went to see him there. I said this was mad \& wd. be eaten up by Germans in an hour. He was doubtful, bit I was determined. I went to see Winston at Admiralty \& met Pr. Louis of Battenberg ${ }^{105}$. I convinced them it was a blunder \& they withdrew the letter! Asquith has seen Burns who is obdurate \& I suppose resigns tomorrow.

Sir Thos. Robinson ${ }^{106}$ (Ag. Gen. Queensland) came 14 B.Sq. at 11 p.m. to say he $\operatorname{Armour}^{107}$ (Amer. meat trust) control Queensland meat stores here and on sea - 2,000 tons meat afloat between Queensland \& U.S. America - they will divert it here if we wish. Austria trying to get a lot of it. Gave him a letter to Llewellyn Smith ${ }^{108}$ (Bd. of Trade) for tomorrow morning.

A. Ponsonby came 11 B.Sq. to ask how we (Peace) are getting on. I told him the 2 points on which I thought Brit. interests were concerned and he agreed they were essential.

He tells me the private M.P.s (Peace) are already split \& they cd. not call a Party meeting.

Many of them think the violation of Luxemburg vital!!!

Not one memb. of Cab. (not even Grey) attaches any importance to this!!'

\footnotetext{
${ }^{104}$ Actually the colony of German South-West Africa (now Namibia). As Colonial Secretary, Harcourt found he had responsibility for planning military action against German colonies.

${ }^{105}$ Prince Louis of Battenberg (1854-1921), German prince who joined the Royal Navy when young; First Sea Lord since1912; forced to resign in October 1914 due to public concern over his German background.

${ }^{106}$ Sir Thomas Robinson (1853-1939), soldier and businessman; Agent-General of Queensland in London, 1910-19.

${ }^{107}$ Jonathan Armour (1863-1927), President of Armour and Co., meatpackers; with other major US packing firms he operated an informal 'meat trust'.

${ }^{108}$ Sir Hubert Llewellyn Smith (1864-1945), civil servant and labour reformer; Permanent Secretary of the Board of Trade, 1907-19.
} 


\section{August, Political Journal.}

'Cab. 3.8.14 (morning)

J. Burns gone.

Simon resigned but sitting here.

J. Morley probably going.

Belgium recd. demand from Germany for neutrality \& has categorically refused.

Germans concentrating at Liege.

Grey "We must support Belgium \& France".

I sd. gt. advantage if Germany declared war on us. ${ }^{109}$

Bonar Law \& Lansdowne seen Asquith - they agreed with Burns, fleet proclamation is a declaration of War.

They attach gt. importance to our supporting Belgium.

Germany offered Belgium neutrality afterwards if they allow passage of German troops.

Lichnowsky "pledges his govt. not to attack French coast with fleet". Grey does not think Lichnowsky authorised to say this.

$£ 4$ mills per month extra wanted for Navy during war.

Asq. army mobilisation now necessary (not for Expeditionary force, but for home safety $\&$ defence. $£ 8$ mills for army mobilisation. ${ }^{110}$

“Crown Princess" German ship with $£ 2$ mills American gold for us been diverted north to Germany - we can’t stop her.

I told Cabinet about meat supplies: what I had done with Sir T. Robinson.

We appoint Committee to deal with food supplies.

? extend Bank Holiday (next Monday) for two days. ${ }^{111}$ Huth Jackson against it.

\footnotetext{
${ }^{109}$ A remark that shows how far Harcourt had come round to accepting that Britain should fight.

${ }^{110}$ Army mobilisation was ordered on the same day, 3 August.
} 
Use postal notes for a few days whilst waiting for $£ 1 \& 10 /-$ notes.

There may be a run on $\mathrm{P}[\mathrm{ost}] . \mathrm{O}[\mathrm{ffice}]$. Savings Bank $£ 150$ mills. deposits.

Grey gave us summary of what he will say in $\mathrm{H}$ of $\mathrm{C}$. today.

Sweden joins Germany in the War if we come in with France. ${ }^{112}$

Asq. then said, "Burns has resigned; Morley, Simon, Beauchamp also going; many others uneasy: the Cabinet with much shattered authority in time of great stress.

Labour will be against us: Irish will act for Ireland. Under other circs. Asq wd have resigned, but no Govt with a majority in $\mathrm{H}$ of C. - dislikes and abhors a coalition experiment none wd like to see repeated. Asq will not separate from Grey - remains in best interests of the country. Asq will not separate from Grey - remains in best interests of the country. Asq "most thankless task to me to go on".

J. Morley made a speech on his reasons.

Simon sd. "if country at war it was the duty of men like himself and the peace party to support the Govt.": he broke down.

Pease, Crewe, Ll.Geo., I, Samuel, Runciman \& Winston subsequently spoke.

An appeal was made by Haldane \& Winston to Simon \& others not to resign now, or at least not announce it today. Simon and J. Morley were willing, Beauchamp not; sd. our party ought to be informed.

No statement will be made by any of them today.

(At Colonial Office - afternoon.)

What about S[tanley, Lord]. Buxton going to South Africa on Saturday: ? convoy ship will contain cyanide, mercury, zinc (contraband) for S. African gold.

\footnotetext{
${ }^{111}$ The Bank Holiday, due on Monday, was eventually extended for three further days, the longest Bank Holiday in British history. The banks' closure allowed time for the government to introduce emergency measures, including a moratorium on debt payments, printing $£ 1$ and 10 shilling (50 pence) notes, and passing a Currency and Banknotes Act which, among other steps, made Scottish and Irish banknotes, as well as postal orders, legal tender. The measures were largely successful: there was no 'run' on banks when they reopened on 7 August and the Bank Rate was reduced to 5\% on 8 August.

${ }^{112}$ In fact, Sweden declared itself neutral on 3 August.
} 
Sir D. de V. Graaf ${ }^{113}$ "We will take German S.W. Africa if you wish."

I sd. "Will you not if I ask it" He sd. "Yes"

I sd. "Often easier to take than to give up at end"

Resumed Cabinet at 6 p.m.

German ultimatum to Belgium come in: very stiff. ${ }^{114}$

Churchill "the Fleet will be absolutely ready by 4 a.m. tomorrow"

Asq. Army mobilisation will be completed by Sunday - we have 3 days more.

Grey will telegraph to Germany tomorrow morning as to their ultimatum to Belgium

\& demand answer.

S. Wales colliers sd. to have struck "won’t dig coal for War”. Since Grey's speech

this afternoon Brace ${ }^{115}$ told them to resume.

Asq. thinks Simon may not resign after all.

Decided we will risk capture of S. Buxton.

Norway to declare which side she takes (? ultimatum from Germany),116

\section{Also filed with 3 August entry is the following Note:}

Harcourt: 'You don't contemplate sending an expeditionary force to France?'

Asquith: 'No, certainly not.'

\section{August}

\section{Notes of Cabinet Meeting}

'Cab. 4.8.14

\footnotetext{
${ }^{113}$ Sir David de Villiers Graaff (1859-1931), businessman, South African MP and close ally of the South African Prime Minister, Louis Botha.

${ }^{114}$ On 2 August the German government sent a note to Belgium demanding free passage of troops across it territory. On 3 August the Belgians rejected the ultimatum.

${ }^{115}$ William Brace (1865-1947), President of the South Wales Miners' Federation, 1912-15.

${ }^{116}$ In fact, there was no German ultimatum to Norway, which remained neutral during the war.
} 
Simon and Beauchamp here pro tem. ${ }^{117}$

We are to fire on German dreadnought (Goeben) in the Mediterranean if it tries to stop French transports: we to stop her getting out to prey on our commerce in the Atlantic. $^{118}$

We are sending an ultimatum to Germany $\&$ to have the answer by midnight Belgium has informed Belgium that her territory will be violated by force of arms. The 'Krone Princessan’ with $£ 2$ mills (American) coin has come into Falmouth and been detained by local military force. The gold is consigned to England, not Germany, though destined for the latter.

Winston says she is only to discharge her bullion and then be released. Grey wants her detained altogether.

The ship we heard of yesterday as going north was the wrong one and had no gold on board

Discussed seizure of German colonies: I said "No, better wait a bit". I told the Cab. I was holding back Dominion Exped. Forces for the present \& they approved.

I spoke about Territorials \& farmers horse \& begged they should not be impounded now in the middle of the harvest.

I want a Committee at once to deal with food distribution.

The Goeben will be warned that if she shoots at French transports we shall sink her. Germany has now declared War on France. I insisted, and Asq. agreed, that orders shd. be sent to our Mediterranean Fleet not to fire on "Goeben" till we have become at war with Germany. Winston was compelled to end these orders \& at once. The wireless was sent off at 12.50 p.m.

\footnotetext{
${ }^{117}$ Simon and Beauchamp had submitted letters of resignation to Asquith, but later withdrew them. Morley and Burns went through with their resignations.

118 The German battlecruiser, Goeben, was operating in the western Mediterranean with its escort vessel, the Breslau. Rather than escaping into the Atlantic, they struck eastwards, evaded the Royal Navy and took refuge in Constantinople (now Istanbul).
} 
There are many German spies here now \& have been for a long time: we have full evidence against them \& shall seize them at once. ${ }^{119}$

Grey read us his telegram to Goschen at Berlin, which is an ultimatum: we say we must have an assurance from Germany - similar to that from France last week - as to the neutrality of Belgium.

Germany said to have sent an ultimatum to Sweden \& may do so to Norway. ${ }^{120}$ Grey wants to offer Holland \& Norway (as well as Belgium a guarantee of future integrity if they will remain neutral now.

In tel. just received by French Embassy it is said that the Germans have penetrated to Verviers between Liege and German frontier.'

\section{Separate Note of a meeting on financial questions, 4 August}

'H of C. Birrell's Rm. 4.8.14

With Ll.Geo. at meeting of commercial men.

St. Aldwyn ${ }^{121}$ \& Aust. Chamb. ${ }^{122}$ with them.

Crewe, Runciman McKenna \& self \& Simon.

Quest. of extension of Moratorium

? suspension of specie payment

Bank Act to be suspended

$£ 1$ and $10 /-$ notes to be issued

Scotch [sic] \& Irish notes to be legal tender

More silver to be coined

\footnotetext{
119 The number of German spies was much smaller than feared and all were quickly rounded up.

${ }^{120}$ In fact, neither Sweden nor Norway was sent an ultimatum by Germany.

${ }^{121}$ Michael Hicks Beach, Earl St. Aldwyn (1837-1916), former Conservative Chancellor of the Exchequer, 1895-1902.

122 Austen Chamberlain (1863-1937), another former Conservative Chancellor of the Exchequer, 190305.
} 
St. Aldwyn wants general moratorium for a month'

\section{Separate Note of Downing Street meeting, 4 August:}

'Tuesday 4.8.14

Went to Downing St. 11.15 p.m.

Grey, P.M., Churchill, Ll.Geo., McKenna there.

German answer unsatisfactory \& Goschen asked for his passports - War Declared.

Sent all my tels. to Cols \& Dominions

Long discussion as to tactics.

Churchill wants to block Amsterdam \& mouth of Rhine, Asq. Grey \& I insisted we wd. not violate neutrality of Holland. Our defence of small nationalities our greatest asset. We insisted on this.

I told them I cd. tomorrow destroy or seize gt. wireless German station in Togoland. May do so tomorrow.

Some discussion about Expeditionary force. I pointed out dangers of doing this to India \& Crown Colonies and home (possible revolution in North). I told Asq. \& Grey this was vital to me. No decision - perhaps discuss tomorrow.

I think L1. Geo. weakening in his peace "convictions" under the impression of mad popular enthusiasm in streets for war.

All the afternoon in Cab. Comm. with Bankers \& Merchants.

I suggested dropping of Bank Rate from 10 to $5 \%$ to give public confidence - high rate no longer of use to bring in gold.' 